\title{
Leaf nitrogen and phosphorus stoichiometry of plant communities in geochemically phosphorus-enriched soils in a subtropical mountainous region, SW China
}

\author{
Kai Yan ${ }^{1}$ Changqun Duan ${ }^{1}$ Denggao $\mathrm{Fu}^{1} \cdot \mathrm{Jie} \mathrm{Li}^{1,2} \cdot$ Michelle H. G. Wong $^{1,3}$. \\ Ling Qian ${ }^{4} \cdot$ Yunxia Tian ${ }^{5}$
}

Received: 12 November 2014 / Accepted: 28 April 2015/Published online: 23 May 2015

(C) Springer-Verlag Berlin Heidelberg 2015

\begin{abstract}
Leaf nitrogen (N) and phosphorus (P) stoichiometry might reflect the biogeochemical features of ecosystems, yet the potential range of stoichiometric flexibility under geochemically P-enriched soils (GPES) is still unclear. Leaf $\mathrm{N}$ and $\mathrm{P}$ of 126 plant species in 70 vegetation plots in GPES were investigated in central Yunnan, southwestern China, and leaf $\mathrm{P}$ fractions (i.e., inorganic vs. organic $\mathrm{P}$ ) of the dominant species were examined. Our objectives were to improve the understanding of the role of soil $\mathrm{N}$ and $\mathrm{P}$ variability in controlling leaf $\mathrm{N}$ and $\mathrm{P}$ stoichiometry of plant communities in GPES. We found that plants in GPES had higher mean leaf $P(4.07 \mathrm{mg} / \mathrm{g})$ and lower N:P ratios (4.94) than average plant values that have been recorded in other parts of the world so far. Some fastgrowing plants had extremely high leaf $\mathrm{P}(>10 \mathrm{mg} / \mathrm{g})$.
\end{abstract}

Changqun Duan

chqduan@ynu.edu.cn

$1 \quad$ Institute of Environmental Sciences and Ecological Restoration and Key Laboratory for Conservation and Utilization of Bio-Resource of Yunnan, Yunnan University, Kunming 650091, China

2 Yunnan Institute of Environment Science, Kunming 650034, China

3 Key Laboratory of Ecosystem Network Observation and Modelling, Institute of Geographic Science and Natural Resources, Chinese Academy of Sciences, Beijing 100101, China

4 National Major Science and Technology Program Management Office for Water Pollution Control and Treatment, Environmental Development Center of Ministry of Environmental Protection of the People's Republic of China, Beijing 100029, China

5 Kunming Institute of Agricultural Science, Kunming 650034, China
Community leaf $\mathrm{N}$ and $\mathrm{P}$ contents increased as soil $\mathrm{N}$ availability increased, but soil $\mathrm{N}$ variability was unrelated to community leaf $\mathrm{N}: \mathrm{P}$. Instead, community leaf $\mathrm{P}$ and $\mathrm{N}: \mathrm{P}$ ratios were primarily determined by soil $\mathrm{P}$; as soil $\mathrm{P}$ availability increased, leaf $P$ increased and leaf N:P significantly decreased. Greater accumulation of inorganic $\mathrm{P}$ relative to organic $\mathrm{P}$ in leaf was the direct driving factor for community leaf $P$ and $N: P$ ratio patterns in GPES. Although soil $\mathrm{P}$ availability was the main controlling factor of leaf N:P patterns, community composition could be manipulated to restore the balance of $\mathrm{N}$ and $\mathrm{P}$ stoichiometry based on the different responses across species and plant types.

Keywords Species-specific responses - Leaf inorganic phosphorus - Leaf organic phosphorus - Geochemically P-enriched soils (GEES) · Central Yunnan

\section{Introduction}

Leaf nitrogen $\left(\mathrm{L}_{\mathrm{N}}\right)$, phosphorus $\left(\mathrm{L}_{\mathrm{P}}\right)$, and nitrogen:phosphorus ratios $\left(\mathrm{L}_{\mathrm{N}: \mathrm{P}}\right)$ (i.e., $\mathrm{N}: \mathrm{P}$ stoichiometry) reflect general ecological characteristics of plants, plant-soil feedbacks, and ecosystem function (Chapin et al. 2011). Leaf $\mathrm{N}: \mathrm{P}$ stoichiometry is a good indicator of biogeochemical features and is a fundamental component in the accurate prediction of ecological responses to global change (Qin et al. 2014; Sistla and Schimel 2012; Sterner and Elser 2002).

Several studies indicated that, moving from cool and temperate to tropical climates, terrestrial ecosystems generally increase in plant $\mathrm{L}_{\mathrm{N}: \mathrm{P}}$ and decrease in $\mathrm{L}_{\mathrm{P}}$ contents (Reich and Oleksyn 2004; Townsend et al. 2007). Lower $L_{P}$ and higher $L_{N: P}$ were found in China compared with 
global averages (Han et al. 2005). These observations are thought to be the result of phosphorus $(\mathrm{P})$ limitations in terrestrial productivity at low latitudes, especially in China (Han et al. 2005; Reich and Oleksyn 2004; Vitousek et al. 2010). Many P-enriched soils exist around the world, which have been neglected by eco-stoichiometry research. Since the end of the 20th century, human activities have resulted in a rapid increase in P-enriched soil regions and the $\mathrm{P}$ limitation pattern has gradually changed in some regions (Elser 2012; Zapata and Roy 2004). In those regions, water safety is seriously threatened and the fitness and growth of plants are facing a new pressure from these altered conditions (Beavers et al. 2013; Bennett and Elser 2011; Wang et al. 2015). Understanding the potential range and mechanisms controlling plant leaf $\mathrm{N}$ and $\mathrm{P}$ stoichiometric variation in P-enriched regions is indispensable to help predict nutrient balance patterns in ecosystem processes using a stoichiometric framework and enhance vegetation management (Sistla and Schimel 2012; Sterner and Elser 2002).

Enormous sedimentary phosphate deposits exist in tropical and subtropical regions, in particular in the Northern Hemisphere, which has led to the development of geochemically P-enriched soils (GPES) regions (Zapata and Roy 2004). Central Yunnan in China is a typical representative GPES region. Previous studies of $L_{P}$ in GPES found conflicting results, with some studies finding forbs with high $L_{P}$ contents in GPES regions (Xiao et al. 2009; Yan et al. 2011). Other studies found that some plants resisted accumulating high $\mathrm{P}$ in leaves, because high internal $\mathrm{P}$ concentrations could cause symptoms of $\mathrm{P}$ toxicity (Hawkins et al. 2008; Silber et al. 2002). The situation for nitrogen $(\mathrm{N})$ was complex, as although a large number studies found that the correlations between $\mathrm{L}_{\mathrm{N}}, \mathrm{L}_{\mathrm{N}: \mathrm{P}}$, and soil $\mathrm{N}$ availability were weak (Kozovits et al. 2007; Mayor et al. 2014; Novotny et al. 2007), some studies reported positive effects of $\mathrm{N}$ addition on $\mathrm{L}_{\mathrm{N}}, \mathrm{L}_{\mathrm{P}}$, and $\mathrm{L}_{\mathrm{N}: \mathrm{P}}$, in N-limited regions (Lü et al. 2012; Perring et al. 2008). Little is known about the effect of $\mathrm{N}$ addition in GPES regions. In short, our understanding of leaf $\mathrm{N}$ and $\mathrm{P}$ stoichiometry of plant communities in GPES is lacking, with such knowledge reflecting the potential range of stoichiometric flexibility related to extreme nutrient conditions.

To answer the above questions, this paper described a study of 70 sample plots in GPES in central Yunnan, China. $\mathrm{L}_{\mathrm{N}}$ and $\mathrm{L}_{\mathrm{P}}$ of 126 plant species, and soil $\mathrm{N}$ and $\mathrm{P}$ availability were investigated. Considering invasive plants leading to the degeneration and $\mathrm{N}_{2}$-fixing plants were dominant in early succession in GPES mountain, we focused on six plant types, e.g., invasive plants, forbs, $\mathrm{N}_{2}$ fixing plants, shrubs, trees, and grasses (Yan et al. 2011). Additionally, Species-specific responses, including leaf $\mathrm{P}$ fractions (i.e., inorganic vs. organic P), were observed for 10 dominant species to further understand community responses.

Our objectives were to (1) assess the $\mathrm{L}_{\mathrm{N}}, \mathrm{L}_{\mathrm{P}}$, and $\mathrm{L}_{\mathrm{N}} \mathrm{P}$ stoichiometry of plant communities in GPES; and (2) understand the roles of soil $\mathrm{N}$ and $\mathrm{P}$ variability in controlling leaf $\mathrm{N}$ and $\mathrm{P}$ stoichiometry of plant communities in GPES. To our knowledge, this is the first study of leaf $\mathrm{N}$ and $\mathrm{P}$ stoichiometry in GPES regions. Our findings will improve the understanding of variations in $\mathrm{N}$ and $\mathrm{P}$ stoichiometry and their responses to global $\mathrm{P}$ change, and facilitate the incorporation of these data into future global biogeochemical models.

\section{Materials and methods}

\section{Study area}

Central Yunnan, China is one of the four largest sedimentary phosphate deposits in the world, along with Khouribga, Morocco, Florida, USA, and Kola, Russia (Zapata and Roy 2004). Most of the GPES and vegetation in this region are located in the mountainous area around the Dianchi and Fuxian Lakes ( $\mathrm{Li}$ et al. 2015) (Fig. 1). In the study area, the annual mean temperature is $14.6{ }^{\circ} \mathrm{C}$ and the annual mean rainfall is $925.4 \mathrm{~mm}$. Under the subtropical semi-humid monsoon, the rainy season lasts from May to October. The zonal vegetation of the study areas is subtropical semi-humid evergreen broad-leaved forest (Tang et al. 2010), and the secondary plant communities around GPES land are dominated by Ageratina adenophora, Chenopodium ambrosioides, Erianthus rufipilus, Themeda hookeri, Coriaria nepalensis, Fragaria nilgerrensis, Ficus tikoua, Rumex hastatus, Cotoneaster microphyllus, and Pinus yunnanensis.

The research region $\left(24^{\circ} 1^{\prime}-25^{\circ} 3^{\prime} \mathrm{N}, 102^{\circ} 23^{\prime}-103^{\circ} 09^{\prime} \mathrm{E}\right)$ was constrained within a narrow elevation range (1980-2210 m) and the main soil types were Ferralsols and Cambisols. The range of soil total $\mathrm{P}$ and $\mathrm{N}$ was $1.47-87.38$ and $0.06-2.66 \mathrm{mg} / \mathrm{g}$, respectively. Soil $\mathrm{P}$ concentrations were generally high and variable, whereas other soil chemical properties were relatively stable, as shown in Table 1.

\section{Sample collection}

Field work was conducted during July and August in 2011. Sampling plots were located in plant communities around GPES. The species richness to area relationship was studied to determine the minimum plot area, which was $25 \mathrm{~m}^{2}$ (Buys et al. 1994). The plots were located at least $1 \mathrm{~km}$ away from residential areas, 
Fig. 1 The research area and the distribution of geochemically phosphorusenriched regions

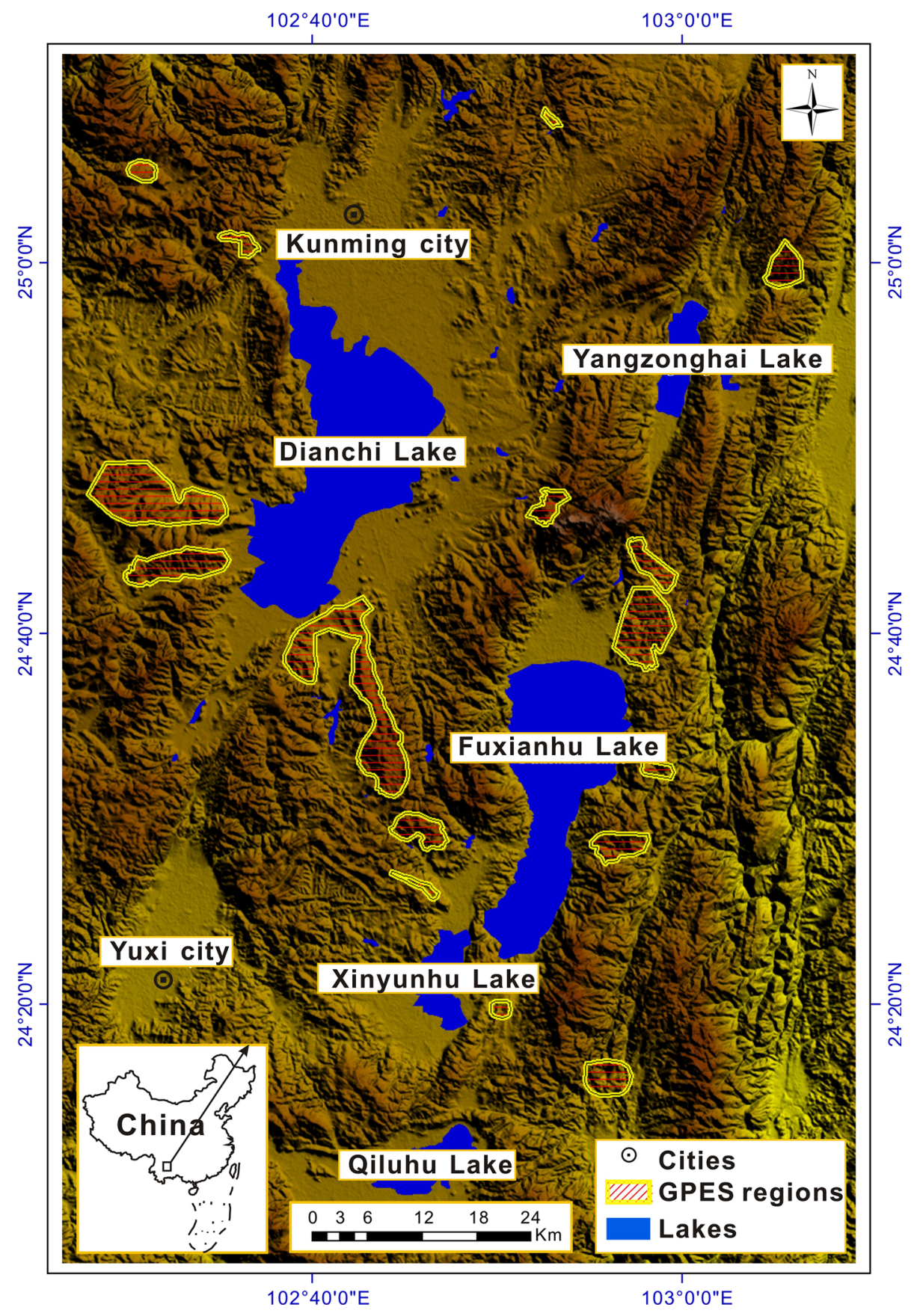

and the distance between plots was greater than $100 \mathrm{~m}$. Plant community composition was described using a relevé plot method, recording species name, number and percent coverage of each species, and growth form of each species.

For leaf sampling, fresh mature leaves were collected for each species (percent coverage $>1 \%$ ) from each plot. For each tree and large shrub species, 10 leaves were sampled from five random individual plants that were exposed to the most direct sunlight (Cornelissen et al.
2003; Richardson et al. 2008). For herbaceous and small shrub species, five whole plants were collected for each species from the most light-exposed locations. Leaf samples were preserved and transported on ice. Leaf samples were collected from a total of 126 plant species (coverage $>1 \%$ ) in 40 families, and most species occurred in multiple plots $($ mean $=6$ plots, median $=4$ plots, range $=1-55$ plots $)$

Soils were sampled from the upper $100 \mathrm{~mm}$ of the mineral horizon to measure soil fertility properties. A mix 
Table 1 Arithmetic mean and coefficient of variation for each of the eight topsoil properties

\begin{tabular}{llc}
\hline Topsoil properties & Mean & CV $(\%)$ \\
\hline Soil total N (mg/kg) & $0.78 \times 10^{3}$ & 67.42 \\
Soil available N (mg/kg) & 87.4 & 79.41 \\
Soil total P (mg/kg) & $6.57 \times 10^{3}$ & 144.1 \\
Soil available P (mg/kg) & 381.54 & 152.99 \\
Soil total K (mg/kg) & $3.36 \times 10^{3}$ & 11.61 \\
Soil available K (mg/kg) & 70.67 & 43.26 \\
Soil organic matter $(\%)$ & 3.21 & 40.50 \\
Soil pH & 6.23 & 19.40 \\
\hline
\end{tabular}

Soil total N, P, available N, and available $\mathrm{P}$ were measured across 70 plots in this paper, and the other indexes were measured by the earlier work (Yan et al. 2011)

of five soil subsamples collected from each plot was used as the plot samples.

\section{Chemical analysis}

Total $\mathrm{N}$ and $\mathrm{P}$ of all leaf samples were measured on ground, oven-dried $\left(60{ }^{\circ} \mathrm{C}\right.$ for $\left.48 \mathrm{~h}\right)$ materials after acid digestion. $\mathrm{N}$ contents were measured using the Kjeldahl method (Ryan et al. 2007). For leaf P, the total P concentration was measured colorimetrically at $700 \mathrm{~nm}$ after reaction with molybdenum blue; inorganic $\mathrm{P}\left(\mathrm{P}_{\mathrm{i}}\right)$ was extracted by shaking $0.2 \mathrm{~g}$ of leaf tissue for $30 \mathrm{~min}$ in $10 \mathrm{~mL}$ of $0.25 \mathrm{M} \mathrm{H}_{2} \mathrm{SO}_{4}$. Organic $\mathrm{P}\left(\mathrm{P}_{\mathrm{o}}\right)$ was calculated as the difference between total $\mathrm{P}$ and $\mathrm{P}_{\mathrm{i}}$ (Mayor et al. 2014).

Soil available $\mathrm{P}$ was determined after extraction with $0.5 \mathrm{M}$ bicarbonate and measured with a spectrophotometer. Soil available $\mathrm{N}$ was analyzed by the alkali-hydro diffusion method using $1 \mathrm{M} \mathrm{NaOH}$. Results were expressed on an oven-dry $\left(105^{\circ} \mathrm{C}\right)$ soil basis (Ryan et al. 2007).

\section{Statistical analysis}

Normality tests were first conducted for the calculated values, and the results that did not show normal distributions were $\log$ transformed before further analyses. Coverweighted mean $\mathrm{L}_{\mathrm{N}}$ and $\mathrm{L}_{\mathrm{P}}$ for each plot were calculated. Both the cover-weighted and species-specific data were directly comparable with assembled data from published results (latitude range from 23 to 25 , reference data) (Han et al. 2005; Reich and Oleksyn 2004; Zhang et al. 2011). The differences in $\mathrm{N}$ and $\mathrm{P}$ stoichiometry among different plant types were compared using one-way analysis of variance.

Regression analysis was used to assess how the total plant community $\mathrm{L}_{\mathrm{N}}, \mathrm{L}_{\mathrm{P}}$, and $\mathrm{L}_{\mathrm{N}: \mathrm{P}}$ stoichiometry (mass ratio) responded to soil $\mathrm{N}$ and $\mathrm{P}$ availability. The total variation explained was the $r^{2}$ for the model using both variables. All values were reported as a percentage of the total variation explained (Richardson et al. 2008). Species-specific responses were assessed for those 10 species that were present in at least 15 plots. Regression analysis was used for the interpretation of leaf total $\mathrm{P}$ variation of each dominant species affected by $\mathrm{P}_{\mathrm{o}}$ and $\mathrm{P}_{\mathrm{i}}$; the variation explained was $r^{2}$ and reported as a percentage.

\section{Results}

\section{Patterns of leaf N, $P$ and N:P ratio across all species and plant types}

Plants (species-specific data) in GPES had high $\mathrm{L}_{\mathrm{P}}$ contents (mean $4.07 \mathrm{mg} / \mathrm{g}$ ) and low $\mathrm{L}_{\mathrm{N}: \mathrm{P}}$ (mean 4.94). No difference was found between species-specific and cover-weighted data (Fig. 2). $\mathrm{L}_{\mathrm{P}}$ contents had the highest variation (coefficient of variation $=67.25 \%$ ), ranging from 1.33 to $16.14 \mathrm{mg} / \mathrm{g}$. Positive correlations were found between $\mathrm{L}_{\mathrm{N}}$ and $\mathrm{L}_{\mathrm{P}}$ contents $(p=0.001)$. Most plants, especially dominant plants, had a medium $\mathrm{L}_{\mathrm{P}}$ content (Fig. 3; Table 3). Invasive plants and forbs had the highest $L_{N}$ and $\mathrm{L}_{\mathrm{P}}$ contents across plant types, and among them, the $\mathrm{L}_{\mathrm{P}}$ contents of Polygonum hydropiper $(16.23 \mathrm{mg} / \mathrm{g})$, Epilobium fangii $(13.44 \mathrm{mg} / \mathrm{g})$, Erigeron acer $(12.23 \mathrm{mg} / \mathrm{g})$, and four other species were larger than $10 \mathrm{mg} / \mathrm{g}$. Shrubs, trees, and grasses had low $\mathrm{L}_{\mathrm{N}}$ and $\mathrm{L}_{\mathrm{P}}$ contents (Fig. 3). The variation in $\mathrm{L}_{\mathrm{N}: \mathrm{P}}$ across plant types was smaller than that of $\mathrm{L}_{\mathrm{N}}$ and $\mathrm{L}_{\mathrm{P}}$, and $\mathrm{L}_{\mathrm{N}: \mathrm{P}}$ was primarily controlled by the variation in $L_{P}$ rather than $L_{N}$ (Fig. 3).

\section{Leaf $N, P$, and $N: P$ ratio responses to soil $N$ and $P$ variability}

With increasing soil $\mathrm{N}$ availability, $\mathrm{L}_{\mathrm{N}}$ of the most species increased except for some $\mathrm{N}_{2}$-fixing plants (e.g., $C$. nepalensis and $F$. nilgerrensis) and the $\mathrm{L}_{\mathrm{P}}$ of $C$. ambrosioides and five other species increased (Table 3). Soil N availability was important for driving both community $\mathrm{L}_{\mathrm{N}}$ (36.0 \%) and $\mathrm{L}_{\mathrm{P}}(13.9 \%)$. The response of $\mathrm{L}_{\mathrm{N}}$ to soil $\mathrm{N}$ availability was greater than that of $\mathrm{L}_{\mathrm{P}}$ (Table 2). Low correlations $(p=0.102)$ were found between soil $\mathrm{N}$ variability and community $\mathrm{L}_{\mathrm{N}: \mathrm{P}}$.

Soil $\mathrm{P}$ was the key factor influencing community $\mathrm{L}_{\mathrm{P}}$ (29.8\%), and $\mathrm{L}_{\mathrm{N}: \mathrm{P}}$ ratios $(43.0 \%)$, but no significant correlations were found between soil $\mathrm{P}$ and community $\mathrm{L}_{\mathrm{N}}(0.06 \%$; Table 2). For the dominant species, increasing soil $\mathrm{P}$ availability led to increased $\mathrm{L}_{\mathrm{P}}$ and decreased $\mathrm{L}_{\mathrm{N}: \mathrm{P}}$ for most species (Table 3). Within-species 
Fig. 2 Comparisons of leaf N, $\mathrm{P}$, and $\mathrm{N}: \mathrm{P}$ in GPES and reference data. See "Statistical analysis " section for details of the reference data
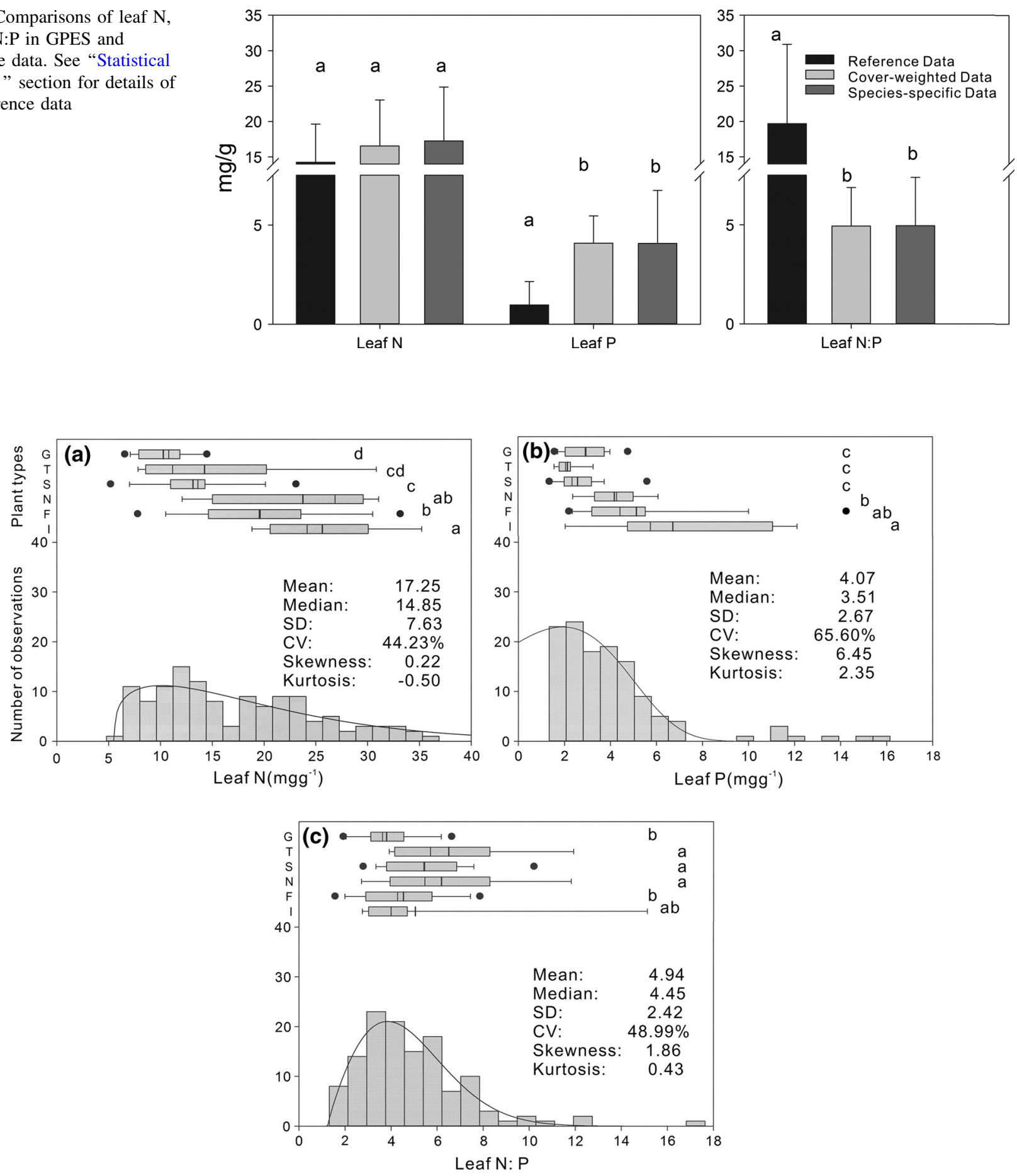

Fig. 3 Histograms showing the distribution of leaf $\mathrm{N}(\mathbf{a})$, leaf $\mathrm{P}(\mathbf{b})$, and leaf $\mathrm{N}: \mathrm{P}$ ratios $(\mathbf{c})$; solid curves in $(\mathbf{a}-\mathbf{c})$ indicate fitted log-normal curves. Leaf $\mathrm{N}, \mathrm{P}$, and ratios among different plant types, $I$ invasive

variations were greater in $\mathrm{L}_{\mathrm{P}}$ than in $\mathrm{L}_{\mathrm{N}}$ (Table 3). $\mathrm{L}_{\mathrm{P}}$ varied 3.5-fold on average in the dominant species examined, and $\mathrm{L}_{\mathrm{N}}$ varied 1.7-fold. Leaf $\mathrm{P}_{\mathrm{i}}$ increased several times from 8.94 fold to 30.88-fold for different species. On average, leaf $\mathrm{P}_{\mathrm{i}}$ accounted for approximately plants, $F$ forbs, $N \mathrm{~N}_{2}$-fixing plants, $S$ shrubs, $T$ trees, $G$ grasses; a-d significantly different $p<0.05$

$50 \%$ of leaf total $\mathrm{P} . \mathrm{P}_{\mathrm{i}}$ relative to $\mathrm{P}_{\mathrm{o}}$ was the primary factor driving community $\mathrm{L}_{\mathrm{P}}$ and $\mathrm{L}_{\mathrm{N}: \mathrm{P}}$ ratios in GPES, as more than $70 \%$ of the variation in leaf total $\mathrm{P}$ was explained by the increase in $\mathrm{P}_{\mathrm{i}}$ for all the dominant plants (Table 3). 
Table 2 The proportion of explained variation in leaf nutrient concentrations attributable to soil available N and P in GPES

\begin{tabular}{llcr}
\hline & Community leaf P (\%) & Community leaf N (\%) & Community leaf N:P (\%) \\
\hline Variation explained by soil P alone & 29.8 & 0.06 & 43.0 \\
Variation explained by soil N alone & 13.9 & 36.0 & 6.7 \\
Variation explained by soil N and P & 48.3 & 36.1 & 46.7 \\
\hline
\end{tabular}

The proportion of explained variation was calculated from model coefficients of determination $\left(r^{2}\right)$ using soil available $\mathrm{N}$ and $\mathrm{P}$ or both. See "Statistical analysis" section for a description of how the proportion of variation was calculated. The number of replicates is 70

\section{Discussion}

\section{The characteristics of leaf $N, P$, and $N: P$ ratios in the GPES}

Our results showed that plants in the GPES region had high $\mathrm{L}_{\mathrm{P}}$ content and low $\mathrm{L}_{\mathrm{N}: \mathrm{P}}$. $\mathrm{L}_{\mathrm{P}}$ content $(4.07 \mathrm{mg} / \mathrm{g})$ was 1.88-3.87 times greater than the reference data (Fig. 2), the average in China, and global averages (Table 4).The mean $\mathrm{L}_{\mathrm{N}: \mathrm{P}}$ was 4.96 at our study site, compared with data from all previous studies that yielded a mean $\mathrm{L}_{\mathrm{N}: \mathrm{P}}$ higher than 10. In particular, $\mathrm{L}_{\mathrm{N}: \mathrm{P}}$ in the GPES region was $23.82 \%$ of the reference data value (19.69). Plant $\mathrm{L}_{\mathrm{N}}$ content $(17.25 \mathrm{mg} / \mathrm{g})$ in this study was less than the average in China, but greater than the other reference data (Table 4).

According to the temperature-plant physiological and soil age hypotheses (Reich and Oleksyn 2004; Lambers et al. 2008; Han et al. 2011), $\mathrm{L}_{\mathrm{N}}$ and $\mathrm{L}_{\mathrm{P}}$ decrease and the $\mathrm{L}_{\mathrm{N}: \mathrm{P}}$ increases towards the equator which is why plant $\mathrm{L}_{\mathrm{N}}$ at our study site and reference data were less than China's and global averages. For the same reason, the $\mathrm{L}_{\mathrm{P}}$ content was smaller and $\mathrm{L}_{\mathrm{N}: \mathrm{P}}$ was larger in the reference data than in China's and global averages, respectively. The above rationale could not explain the extreme high $\mathrm{L}_{\mathrm{P}}$ content and low $\mathrm{L}_{\mathrm{N}: \mathrm{P}}$ found in our study site in Central Yunnan, China, and the high soil $\mathrm{P}$ situation could be a key factor controlling those patterns.

The differences in $\mathrm{L}_{\mathrm{N}}$ and $\mathrm{L}_{\mathrm{P}}$ occurred across plant types, as more ruderal species and fewer stress-tolerant species in the community (with different metabolism) had high $\mathrm{L}_{\mathrm{N}}$ and $\mathrm{L}_{\mathrm{P}}$ contents (Güsewell 2004; Ratnam et al. 2008). For instance, trees (i.e., P. yunnanensis) and grasses (i.e., E. rufipilus and T. hookeri) had lower $\mathrm{L}_{\mathrm{N}}$ and $\mathrm{L}_{\mathrm{P}}$ contents; invasive plants and forbs had the highest $\mathrm{L}_{\mathrm{N}}$ and $\mathrm{L}_{\mathrm{P}}$ contents across plant types (Fig. 3; Table 3).Some invasive plants and forbs with extremely high $\mathrm{L}_{\mathrm{P}}$ content, e.g., $P$. hydropiper, E. fangii, and E. acer, were previously found by Xiao et al. (2009) in another GPES region in southwest China.

$\mathrm{L}_{\mathrm{N}}$ : $\mathrm{P}$ was significantly higher in trees and shrubs than in forbs at our study site, consistent with higher $\mathrm{L}_{\mathrm{N}: \mathrm{P}}$ in longlived, slow-growing species than in short-lived, fast- growing species, as previously identified (Güsewell 2004). Although previous studies found more grasses and fewer forbs in vegetation with a high $\mathrm{L}_{\mathrm{N}: \mathrm{P}}$ ratio (Güsewell 2004; Han et al. 2005; Ratnam et al. 2008), no significant difference was found between the $\mathrm{L}_{\mathrm{N}}$ : P ratio in these plant types in GPES (Fig. 3), which could be explained if the $\mathrm{L}_{\mathrm{N}: \mathrm{P}}$ ratio in GPES was primarily constrained by soil $\mathrm{P}$ availability compared to phylogeny (Ågren and Weih 2012). $L_{N: P}$ ratios across different plant types varied less than $\mathrm{N}$ or $\mathrm{P}$ alone because of the highly positive correlations between $L_{N}$ and $L_{P}$ (Fig. 3), which reflected a fundamental feature of the plant kingdom with respect to leaf $\mathrm{N}$ and $\mathrm{P}$ stoichiometry in GPES (Han et al. 2005; McGroddy et al. 2004).

By comparing the reference data and previous results from Central Yunnan (Hou et al. 2010) with results obtained in this study, it was determined that geochemical features of GPES were the most important drivers of leaf $\mathrm{N}$ and $\mathrm{P}$ stoichiometry at this site, rather than other factors such as longitude and latitude, climate, and plant type.

\section{The role of soil $P$ in controlling $N$ and $P$ stoichiometry of plant communities}

The variation in soil $\mathrm{P}$ availability could affect $\mathrm{P}$ use and the nutrient allometric accumulation of plants, and thus affect the leaf $\mathrm{N}$ and $\mathrm{P}$ stoichiometry patterns and ecological strategy (Mayor et al. 2014). Our results showed that soil in the GPES region had extremely high total $\mathrm{P}$ $\left(6.57 \times 10^{3} \mathrm{mg} / \mathrm{kg}\right)$ and available P content $(381.54 \mathrm{mg} /$ $\mathrm{kg}$ ), which were significantly higher than the results obtained by Hou et al. (2010) from non-GPES regions in Central Yunnan. The soil $\mathrm{P}$ level in GPES in Central Yunnan was significantly higher than the P-enriched threshold identified by Delorme et al. (2000), where GPES had higher soil $\mathrm{P}$ content and variability, and was very different from other P-enriched regions identified in earlier studies, e.g., pasture and farmland (Delorme et al. 2000; Read 2012; Sharma and Sahi 2005).

$\mathrm{P}$ forms in leaves were relatively variable, as plants could store not only $\mathrm{P}_{\mathrm{o}}$ but also $\mathrm{P}_{\mathrm{i}}$ in leaves. The $\mathrm{P}_{\mathrm{o}}-\mathrm{P}_{\mathrm{i}}$ pattern reflected the soil nutrient availability and the 


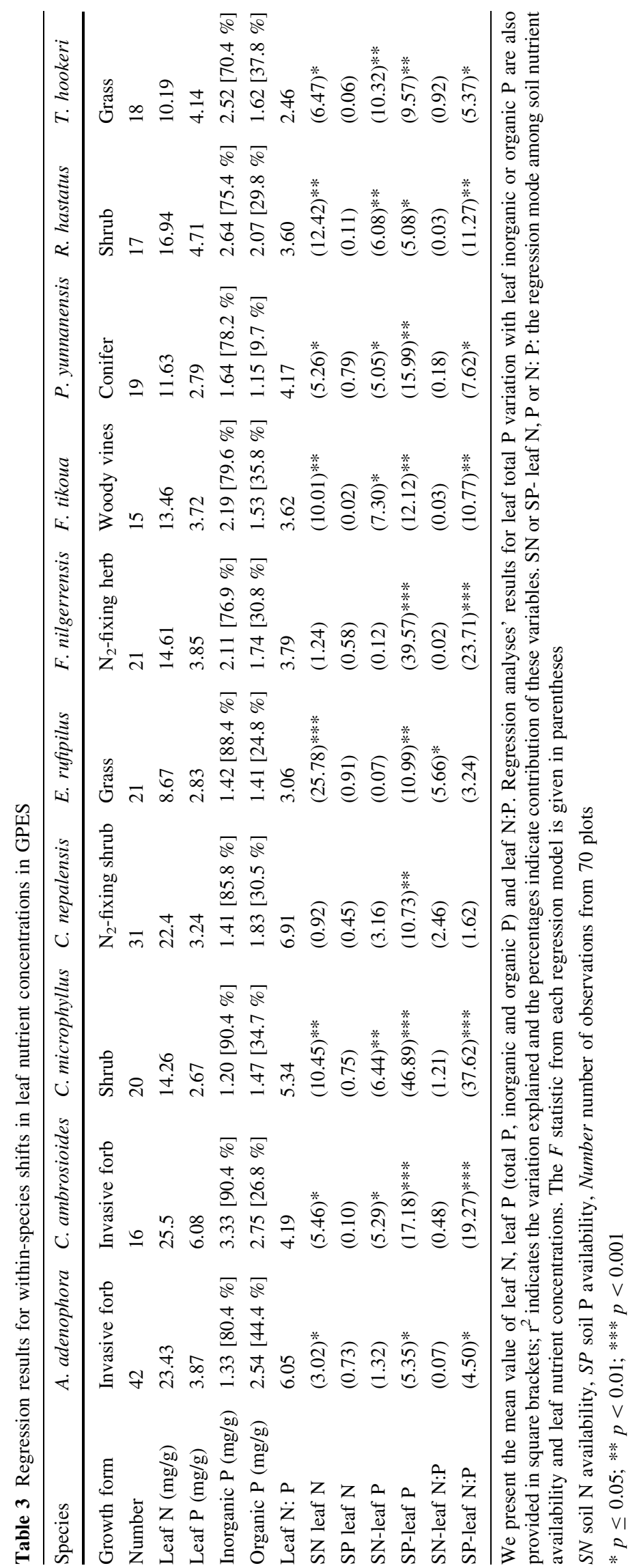


Table 4 Comparisons of leaf nitrogen (N), phosphorus (P) and N:P among studies

\begin{tabular}{|c|c|c|c|c|c|c|c|c|}
\hline \multirow[t]{2}{*}{ Study region } & \multirow[t]{2}{*}{ Latitude } & \multicolumn{2}{|c|}{ Leaf $N$} & \multicolumn{2}{|c|}{ Leaf $P$} & \multicolumn{2}{|c|}{$\begin{array}{l}\text { Leaf } \mathrm{N}: \mathrm{P} \\
\text { ratios }\end{array}$} & \multirow[t]{2}{*}{ Date source } \\
\hline & & A.M. & $\mathrm{CV}$ & A.M & $\mathrm{CV}$ & A.M. & $\mathrm{CV}$ & \\
\hline $\begin{array}{l}\text { Central Yunnan of China (Phosphorus- } \\
\text { enriched soils regions) }\end{array}$ & 24 & 17.25 & 42.31 & 4.07 & 67.25 & 4.96 & 48.13 & This study (species-specific data) \\
\hline $\begin{array}{l}\text { Reference data (Tropical and } \\
\text { subtropical regions) }\end{array}$ & $23-25$ & 14.24 & 37.85 & 0.97 & 121.65 & 19.69 & 56.83 & $\begin{array}{l}\text { Han et al. (2005); Reich and Oleksyn } \\
\text { (2004); Zhang et al. (2011) }\end{array}$ \\
\hline China 1 & $18-49$ & 20.20 & 41.63 & 1.46 & 67.81 & 16.30 & 57.18 & Han et al. (2005) \\
\hline China 2 & $18-52$ & 19.96 & 41.38 & 1.41 & 79.43 & 17.00 & 53.47 & Zhang et al. (2011) \\
\hline Global 1 & - & 20.60 & 59.37 & 1.99 & 74.87 & 12.70 & 53.70 & Elser et al. (2000) \\
\hline Global 2 & $1-68$ & 20.10 & 43.33 & 1.77 & 63.28 & 13.80 & 68.62 & Reich and Oleksyn (2004) \\
\hline
\end{tabular}

$A M$ arithmetic mean $(\mathrm{mg} / \mathrm{g}), C V$ coefficient of variation $(\%)$

nutrient use strategy of plants, thus further affecting the biogeochemical cycles of plant communities (Ågren and Weih, 2012; Mayor et al. 2014).

Our results showed that soil $\mathrm{P}$ availability was the main driver of $\mathrm{L}_{\mathrm{P}}(29.8 \%, p=0.000)$ and $\mathrm{L}_{\mathrm{N}: \mathrm{P}}(43.0 \%$, $p=0.000)$. Additionally, the variations in leaf total $\mathrm{P}$ were explained primarily by the increase in $\mathrm{P}_{\mathrm{i}}$ relative to $\mathrm{P}_{\mathrm{O}}$ (Table 3).We found that both the content and proportion of $\mathrm{P}_{\mathrm{i}}$ in leaves were higher in the GPES region (content: from 1.22 to $3.33 \mathrm{mg} / \mathrm{g}$; proportion: approximately $50 \%$ ) than previous results (content: less than $0.5 \mathrm{mg} / \mathrm{g}$; proportion: less than $30 \%$ ) (Close and Beadle 2004; Mayor et al. 2014). Under high soil $P$ conditions, plants could store higher levels of $\mathrm{P}_{i}$ in leaf cytoplasm and vacuoles as storage materials from luxury $\mathrm{P}$ accumulation (Close and Beadle 2004; Mayor et al. 2014).

Various studies found that the increase in soil $\mathrm{P}$ availability could lead to an increase in community $\mathrm{L}_{\mathrm{P}}$, and a decrease in community $\mathrm{L}_{\mathrm{N}: \mathrm{P}}$ (Reich and Oleksyn 2004; Richardson et al. 2008). Some other studies indicated that plants could reject accumulating high $\mathrm{P}$ in leaves to prevent $\mathrm{P}$ toxicity in P-enriched situations and alter the pattern described above (Hawkins et al. 2008; Silber et al. 2002). Our results for plant communities in GPES support the above pattern, that with increased soil $\mathrm{P}, \mathrm{L}_{\mathrm{P}}$ increased and $\mathrm{L}_{\mathrm{N}: \mathrm{P}}$ decreased, which could be explained as follows: (1) plants living in this area are adapted to high soil $\mathrm{P}$ through evolution and long-term selective processes; (2) most plants, especially dominant plants, had a medium $\mathrm{L}_{\mathrm{P}}$ content, at which $\mathrm{P}$ level the symptoms of $\mathrm{P}$ toxicity might not be serious.

\section{The relationship between soil $\mathbf{N}$ and $\mathbf{N}$ and $\mathbf{P}$ stoichiometry of plant communities}

$\mathrm{N}$ in soil was the other key factor besides $\mathrm{P}$ affecting the leaf $\mathrm{N}$ and $\mathrm{P}$ stoichiometry patterns and ecological strategy.
On a global and continental scale, increasing soil $\mathrm{N}$ availability could lead to an increase in community $\mathrm{L}_{\mathrm{N}}$. On a regional and local scale, however, this situation has become more complex. A large number of studies found that the correlations between $\mathrm{L}_{\mathrm{N}}, \mathrm{L}_{\mathrm{N}} \mathrm{P}$, and soil $\mathrm{N}$ availability could be weakened by physiological limitations in $\mathrm{N}$ storage (as structural compounds) in leaves (Kozovits et al. 2007; Mayor et al. 2014; Novotny et al. 2007), but some studies reported positive effects of $\mathrm{N}$ addition on $\mathrm{L}_{\mathrm{N}}, \mathrm{L}_{\mathrm{P}}$, and $\mathrm{L}_{\mathrm{N}: \mathrm{P}}$ in N-limited regions (Lü et al. 2012; Perring et al. 2008).

Our results showed that soil $\mathrm{N}$ in the GPES region was not high (total N: $0.78 \times 10^{3} \mathrm{mg} / \mathrm{kg}$; available $\mathrm{N}: 87.4 \mathrm{mg}$ / $\mathrm{kg}$ ), similar to results obtained by Hou et al. (2010) from non-GPES in Central Yunnan. It is hard to identify nutrient limitation from the mean soil $\mathrm{N}$ contents (Han et al. 2011); the mean $\mathrm{L}_{\mathrm{N}: \mathrm{P}}$ found in GPES was just 4.96; therefore, according to the eco-stoichiometry theory, $\mathrm{N}$ was limited at our study site (Güsewell 2004).

In the GPES region, we found that community $\mathrm{L}_{\mathrm{N}}$ increased $(36.0 \%)$ following an increase in soil $\mathrm{N}$ availability. Specifically, we found that any increase in soil $\mathrm{N}$ availability would promote the accumulation of $\mathrm{L}_{\mathrm{N}}$ directly by individual plants (Table 3 ). Additionally, we found that $\mathrm{N}$ could increase the efficiency of $\mathrm{P}$ use and concentration in the plant community, and community $\mathrm{L}_{\mathrm{P}}$ increased following an increase in soil $\mathrm{N}$ availability. A synergistic effect was found between soil $\mathrm{N}$ and $\mathrm{P}$ availability in driving the community $L_{P}$ pattern, as variation explained by both soil $\mathrm{N}$ and $\mathrm{P}(48.3 \%)$ was significantly higher than that by soil $\mathrm{N}(13.9 \%)$ or soil P $(29.8 \%)$ alone (Table 2). Especially under nutrient limitation, both $\mathrm{N}$ and $\mathrm{P}$ can stimulate growth or other processes because $\mathrm{N}$ supply often influences how efficiently $\mathrm{P}$ is acquired and used, and vice versa (Güsewell et al. 2003; Güsewell 2004), and the above results further support that $\mathrm{N}$ was limited in GPES. 
The increase in soil $\mathrm{N}$ availability led to increased community $\mathrm{L}_{\mathrm{N}}(p=0.001)$ and $\mathrm{L}_{\mathrm{P}}$ contents $(p=0.017)$ in GPES. However, low correlations were found between soil $\mathrm{N}$ availability and community $\mathrm{L}_{\mathrm{N}: \mathrm{P}}$ because of the stability of $\mathrm{L}_{\mathrm{N}}$ with physiological limitation of $\mathrm{N}$ storage (as structural compounds) in leaves and the great variability of $\mathrm{L}_{\mathrm{P}}$ in response to soil $\mathrm{P}$ availability (Fig. 3; Table 3). This result was similar to results obtained from empirical studies of N and P stoichiometry (Güsewell 2004; Richardson et al. 2008). Considering the large variation in soil $\mathrm{N}$ availability, perhaps soil $\mathrm{N}$ could also alter community composition to indirectly drive community $\mathrm{N}$ and $\mathrm{P}$ stoichiometry, but further study is necessary to confirm this hypothesis.

$\mathrm{N}$ limitation to plant growth and other ecosystem processes, e.g., biogeochemical cycles, is widespread in GPES. In contrast, $\mathrm{N}_{2}$-fixing plants (e.g.C. nepalensis) had highL $\mathrm{L}_{\mathrm{N}}$ contents, and $\mathrm{L}_{\mathrm{N}}$ contents were less affected by soil $\mathrm{N}$ availability, which could stimulate $\mathrm{N}$ cycling (Chaer et al. 2011; Walker et al. 2003). Some $\mathrm{N}_{2}$-fixing plants could accumulate P (Sharma et al. 2007), but could also enhance soil quality (soil $\mathrm{C}$ and $\mathrm{N}$, infiltration, and soil particles) (Chaer et al. 2011), and thus coordinate the balance of $\mathrm{N}$ and $\mathrm{P}$ stoichiometry. These plants might be potential candidates for promoting succession and enhancing ecological function of GPES ecosystems, but further long-term field experiments are required.

\section{Conclusion}

Plants in GPES had much higher $\mathrm{L}_{\mathrm{P}}$ and lower $\mathrm{L}_{\mathrm{N}: \mathrm{P}}$ ratios than tropical and subtropical reference data, China's averages, and global averages. Because of high soil $\mathrm{P}$ availability in GPES, a large amount of $P_{i}$ accumulation in leaves was the key reason for those patterns. Community $\mathrm{L}_{\mathrm{N}}$ and $\mathrm{L}_{\mathrm{P}}$ contents increased following the increase in soil $\mathrm{N}$ availability. Community leaf $\mathrm{P}$ and $\mathrm{N}: \mathrm{P}$ was primarily determined by soil $\mathrm{P}$ availability because of the stability of $\mathrm{L}_{\mathrm{N}}$ and a large amount of $\mathrm{P}$ could accumulate in leaves as inorganic forms responding to elevated soil $\mathrm{P}$ availability. Although community $\mathrm{N}$ and $\mathrm{P}$ stoichiometry was mainly driven by the special geochemical features in GPES, plant type and nutrient strategy were contributing factors. Regulating community composition is suggested as a promising approach to restore the balance of $\mathrm{N}$ and $\mathrm{P}$ stoichiometry and to promote biogeochemical cycles in GPES, especially using $\mathrm{N}_{2}$-fixing plants.

Acknowledgments We thank Prof. Shengrui Wang from Chinese research academy of environmental sciences, Prof. Cindy Q. Tang from Yunnan University, Prof. Masahiko Ohsawa from the University of Tokyo, Anne Serra from Macalester College and anonymous reviewers, whose valuable comments and suggestions greatly helped us to improve the paper. We thank associate Prof. Guosheng Zhang from Yunnan University for soil identification, and also associate Prof. Huanchong Wang from Yunnan University for plant identification. This research was sponsored by National Key Sciences and Technology Program for Water Solutions of China (2012ZX07102-003), National Natural Science Foundation of China (U1133604, 30760049), the Scientific Research and Technological Development Project of Yunnan (2012T001)

\section{References}

Ågren GI, Weih M (2012) Plant stoichiometry at different scales: element concentration patterns reflect environment more than genotype. New Phytol 194:944-952

Beavers C, Ellis R, Hanlon CDE, MacDonald G (2013) An overview of phosphate mining and reclamation in Florida. Available at: http://soils.ifas.ufl.edu/docs/pdf/academic/papers/Beavers_Casey_ No_Embargo.pdf

Bennett E, Elser J (2011) A broken biogeochemical cycle. Nature 478:29-31

Buys M, Maritz J, Boucher C, Van Der Walt J (1994) A model for species-area relationships in plant communities. J Veg Sci 5:63-66

Chaer GM, Resende AS, Campello EFC, de Faria SM, Boddey RM (2011) Nitrogen-fixing legume tree species for the reclamation of severely degraded lands in Brazil. Tree Physiol 31:139-149

Chapin FS III, Matson PA, Vitousek PM (2011) Principles of terrestrial ecosystem ecology, 2nd edn. Springer Science \& Business Media, New York

Close DC, Beadle CL (2004) Total, and chemical fractions, of nitrogen and phosphorus in Eucalyptus seedling leaves: effects of species, nursery fertiliser management and transplanting. Plant Soil 259:85-95

Cornelissen JHC, Lavorel S, Garnier E, Diaz S, Buchmann N, Gurvich DE, Reich PB, Ter Steege H, Morgan HD, Van Der Heijden MGA, Pausas JG, Poorter H (2003) A handbook of protocols for standardised and easy measurement of plant functional traits worldwide. Aust J Bot 51:335-380

Delorme TA, Angle JS, Coale FJ, Chaney RI (2000) Phytoremediation of phosphorus-enriched soils. Int $\mathrm{J}$ Phytorem 2(2):173-181

Elser JJ (2012) Phosphorus: a limiting nutrient for humanity? Curr Opin Biotechnol 23(6):833-838

Elser JJ, Fagan WF, Denno RF, Dobberfuhl DR, Folarin A, Huberty A, Interlandi S, Kilham SS, McCauley E, Schulz KL (2000) Nutritional constraints in terrestrial and freshwater food webs. Nature 408:578-580

Güsewell S (2004) N:P ratios in terrestrial plants: variation and functional significance. New Phytol 164:243-266

Güsewell S, Koerselman W, Verhoeven JT (2003) Biomass N:P ratios as indicators of nutrient limitation for plant populations in wetlands. Ecol Appl 13(2):372-384

Han W, Fang J, Guo D, Zhang Y (2005) Leaf nitrogen and phosphorus stoichiometry across 753 terrestrial plant species in China. New Phytol 168:377-385

Han W, Fang J, Reich PB, Ian Woodward F, Wang Z (2011) Biogeography and variability of eleven mineral elements in plant leaves across gradients of climate, soil and plant functional type in China. Ecol Lett 14(8):788-796

Hawkins HJ, Hettasch H, Mesjasz-Przybylowicz J, Przybylowicz W, Cramer MD (2008) Phosphorus toxicity in the Proteaceae: a problem in post-agricultural lands. Sci Hortic 117:357-365

Hou X, Duan C, Tang CQ, Fu D (2010) Nutrient relocation, hydrological functions, and soil chemistry in plantations as 
compared to natural forests in central Yunnan. China Ecol Res 25(1):139-148

Kozovits A, Bustamante M, Garofalo C, Bucci S, Franco A, Goldstein G, Meinzer F (2007) Nutrient resorption and patterns of litter production and decomposition in a Neotropical Savanna. Funct Ecol 21:1034-1043

Lambers H, Raven JA, Shaver GR, Smith SE (2008) Plant nutrientacquisition strategies change with soil age. Trends Ecol Evol 23(2):95-103

Li LP, Liu L, Wang SR, Liu WB, Jiao LX, Yang Y, Yang R (2015) Spatial distribution of phosphorus fractions in sediment and the potential mobility of phosphorus in Dianchi Lake. Environ Earth Sci. doi:10.1007/s12665-015-4151-y

Lü XT, Kong DL, Pan QM, Simmons ME, Han XG (2012) Nitrogen and water availability interact to affect leaf stoichiometry in a semi-arid grassland. Oecologia 168:301-310

Mayor JR, Wright SJ, Turner BL (2014) Species-specific responses of foliar nutrients to long-term nitrogen and phosphorus additions in a lowland tropical forest. J Ecol 102:36-44

McGroddy ME, Daufresne T, Hedin LO (2004) Scaling of C:N:P stoichiometry in forests worldwide: implications of terrestrial redfield-type ratios. Ecology 85:2390-2401

Novotny AM, Schade JD, Hobbie SE, Kay AD, Kyle M, Reich PB, Elser JJ (2007) Stoichiometric response of nitrogen-fixing and non-fixing dicots to manipulations of $\mathrm{CO}_{2}$, nitrogen, and diversity. Oecologia 151:687-696

Perring MP, Hedin LO, Levin SA, McGroddy M, Mazancourt DC (2008) Increased plant growth from nitrogen addition should conserve phosphorus in terrestrial ecosystems. Proc Natl Acad Sci 105:1971-1976

Qin Y, Yi S, Ren S, Li N, Chen J (2014) Responses of typical grasslands in a semi-arid basin on the Qinghai-Tibetan Plateau to climate change and disturbances. Environ Earth Sci 71(3):1421-1431

Ratnam J, Sankaran M, Hanan NP, Grant RC, Zambatis N (2008) Nutrient resorption patterns of plant functional groups in a tropical savanna: variation and functional significance. Oecologia 157:141-151

Read JJ (2012) Spring Nitrogen fertilization of ryegrass-bermudagrass for phytoremediation of phosphorus-enriched soils. Agron J 104(4):908-916

Reich PB, Oleksyn J (2004) Global patterns of plant leaf N and P in relation to temperature and latitude. Proc Natl Acad Sci USA 101:11001-11006

Richardson SJ, Allen RB, Doherty JE (2008) Shifts in leaf N:P ratio during resorption reflect soil $\mathrm{P}$ in temperate rainforest Functional. Ecology 22:738-745
Ryan J, Estefan G, Rashid A (2007) Soil and plant analysis laboratory manual. ICARDA, pp 55-133

Sharma NC, Sahi SV (2005) Characterization of phosphate accumulation in Lolium multiflorum for remediation of phosphorusenriched soil. Environ Sci Technol 39(14):5475-5480

Sharma NC, Starnes DL, Sahi SV (2007) Phytoextraction of excess soil phosphorus. Environ Pollut 146:120-127

Silber A, Ben-Jaacov J, Ackerman A, Bar-Tal A, Levkovitch I, Matsevitz-Yosef T, Swartzberg D, Riov J, Granot D (2002) Interrelationship between phosphorus toxicity and sugar metabolism in Verticordia plumosa L. Plant Soil 245(2):249-260

Sistla SA, Schimel JP (2012) Stoichiometric flexibility as a regulator of carbon and nutrient cycling in terrestrial ecosystems under change. New Phytol 196:68-78

Sterner RW, Elser JJ (2002) Ecological stoichiometry: the biology of elements from molecules to the biosphere. Princeton University Press, Princeton

Tang CQ, Zhao MH, Li XS, Ohsawa M, Ou XK (2010) Secondary succession of plant communities in a subtropical mountainous region of SW China. Ecol Res 25:149-161

Townsend AR, Cleveland CC, Asner GP, Bustamante MMC (2007) Controls over foliar N:P ratios in tropical rain forests. Ecology 88(1):107-118

Vitousek PM, Porder S, Houlton BZ, Chadwick OA (2010) Terrestrial phosphorus limitation: mechanisms, implications, and nitrogenphosphorus interactions. Ecol Appl 20:5-15

Walker LR, Clarkson BD, Silvester WB, Veverley RC (2003) Colonization dynamics and facilitative impacts of a nitrogenfixing shrub in primary succession. J Veg Sci 14(2):277-290

Wang SR, Meng W, Jin XC, Zheng BH, Zhang L, Xi HY (2015) Ecological security problems of the major key lakes in China. Environ Earth Sci. doi:10.1007/s12665-015-4191-3

Xiao GL, Zhang TX, Yu H, Huang H, Gupta D (2009) Uptake and accumulation of phosphorus by dominant plant species growing in a phosphorus mining area. J Hazard Mater 171:542-550

Yan K, Fu DG, He F, Duan CQ (2011) Leaf nutrient stoichiometry of plants in the phosphorus-enriched soils of the Lake Dianchi watershed, southwestern China. Chin J Plant Ecol 35:353-361

Zapata F, Roy RN (2004) Use of phosphate rocks for sustainable agriculture. Food and Agriculture Organization (FAO) of the Unites Nations, Rome, pp 1-148

Zhang SB, Zhang JL, Slik J, Cao KF (2011) Leaf element concentrations of terrestrial plants across China are influenced by taxonomy and the environment. Glob Ecol Biogeogr 21:809-818 